\title{
Church in the live and teaching of theologian Stanislaw Piotrowski
}

The topic of interest of this article is the Church in the life and teaching of theologian Stanislaw Piotrowski along with its reflection and history of this community in his life. What is even more noteworthy is the fact that the professor in the Archdiocesan Higher Seminary in Bialystok did not become famous for the number of written scientific texts, but rather than for an extraordinary ability to discover God and strong keeping the faith despite adversities. The goal of life of 'seeker theologian' was the implementation of following magisterium of the Church as well as love for community of the Church in students' hearts and minds. The consequence of longstanding analysis of documents, instructions and didactic work resulted in publishing his two books: Built on the Rock and One, Holy, Catholic, Apostolic. The main aim that motivated this article was also providing answers to sources of ecclesiology according to Fr. Piotrowski. Research of his scientific output developed in four points requires a short assessment of what he wrote. By making such an attempt, it was necessary to remind the most important facts of priest's life - time spent in family house, vocation to priestly service and undertaken academic work. Conclusions resulting from literature output led to a number of conclusions: Stanislaw Piotrowski's ecclesiology complies with tradition of the Church, follows from conciliar teaching and has got deep roots in the Bible. Although Piotrowski does not insert any novelty to its content, he faithfully conveys teaching of the Church and accordingly does it in an original way in the benefit of reaching a potential recipient.

Key words: Church, love for the Church, Built on the Rock, community, Stanislaw Piotrowski, catechesis, teaching of theologian. 
Fundamental theology

The 20th century was a period of dynamic flowering of Catholic ecclesiology, stimulated by renewal of both Biblical and patristic studies as well as the development of liturgical movement. The Second Vatican Council was an invaluable event of that time within the Church, which was inspired by pre-conciliar directions of reforms and accordingly initiated a new perspective, which can be named the perspective of personalistic teaching of the Church. Because the above-mentioned Church has got a personal character, it stems from Jesus of Nazareth and realizes among the People of God. Amongst inspiration of that time of development within the Church, it was the role of secular people that became particularly emphasized. Moreover, they were ecumenical tendencies which became clear along with resurgence of liturgy, which influenced a deeper understanding of the Church. Aside from category 'Mystici Corporis', it was included the idea of the Church as Communio of the People of God.

These circumstances formed a new way of interpretation of ecclesiological issues by theologians. It was priest and professor of the Archdiocesan Higher Seminary in Bialystok - Stanislaw Piotrowski, who belonged to them. What did Fr. Stanislaw Piotrowski write about the Church? Where and when? In what way his writing entailed his personal life as well as changes taking place in the Church? What was the shape of academic direction which was lectured by him and what were the subjects of his particular interest?

\section{Way to ecclesiology}

Circumstances of human life, historical situation, political climate, cultural environment, religious experience, economic family situation - these are factors that have an essential impact on parenting.

During the childhood, Fr. Stanislaw Piotrowski enjoyed both closeness and love from his loved ones: mother and father. His parents were aware of a duty of concern for moral and religious upbringing of their children. Moreover, (however)were clear on the fact that unity of the whole family should be built only in the Church and Jesus' teaching as well. Consequently, all their might and strength to raise their son was learnt from the Church, which distinctively penetrated their life through sacrament of the Eucharist. This particular meeting with Eucharistic Christ gave them power to raise Stanislaw in a spirit of community of the Lord's house. They lived in it being both united with love and focused on prayer. Stanislaw's parents knew the way leading 
to the Holy Trinity Church in Suprasl well, from which they returned to their daily responsibilities spiritually strengthened.

Having such parents and growing in such a family atmosphere, priest Stanislaw remained in the house of God connected to its respect, love and obedience ties since childhood.

As the prisoner of Ostaszkow, Stanislaw Piotrowski found himself Fundamental theology in the Theological Seminary in Bialystok on February 3, 1946. While being a pupil, he was characterized by an extraordinary ability to discover God as well as strong keeping in faith, despite adversities.

There is no doubt that both sem. and doctoral studies in Bialystok and Lublin extended Fr. Piotrowski's knowledge about dogmatic theology. It can be concluded that they reinstated his love towards the Church, in which he started even more to perceive Mystical Body of Christ as well as Communio of people of God.

As Piotrowski mentions in one of his articles: 'I studied textbook dogmatics, I found immortal Tanqueray, and I was weaned on him'. ${ }^{1}$

Acquired knowledge during his studies did not only limit itself to knowledge from the one particular textbook. A young doctoral student gave himself over to studying theological contents of treaties from a four-volume work by Maciej Sieniatycki entitled 'Zarys Dogmatyki Katolickiej' ('The Profile Of Catholic Dogmatics') (publ. in Cracow 1928). Fr. Stanislaw admitted that during his studies in Lublin he willingly used and liked as well a four-volume textbook entitled Sacrae Theologiae Summa, established by The Apostolic Constitution Deus Scientiarum Dominus (publ. in Madrid in the years 1952-1961)2. He did not part with Enchirydion Symbolorum by Denzinger for years. Apart from scientific reflexion on ecclesiology of the People of God, he devoted himself to ministry and thereby he put theory into practice. As his fellow student Kulakowski recalls: 'In the course of doctoral studies in the years 1951-1961, priest Stanislaw Piotrowski was an active participant in life of the Archdiocese. He worked as an academic priest and a prefect in high schools as well in a parish church in Bialystok'. ${ }^{3}$ He took the doctor's degree in the Catholic University of Lublin in 1960

$1 \quad$ S. Piotrowski, Impresje na temat wykładów z teologii dogmatycznej $w$ latach 1961-1991 wypowiedziane na sympozjum $w$ dniu 16.11.1991 r. z okazji jubileuszu 30-lecia pracy profesorskiejw Wyższym Seminarium Duchownym w Biatymstoku, WKAB 17(1991) no. 4, p. 102.

$2 \quad$ Ibidem, p. 103.

3 K. Kułakowski, Profesorowie i wykładowcy, [in:] Archidiecezjalne Seminarium Duchowne w Białymstoku 1945-1995, S. Hołodok ed., Białystok 1995, p. 84. 
on the grounds of the dissertation: 'The Union of non-Catholics with the Roman Catholic Church in the light of post-Tridentine theology'.

Fundamental theology

\section{Lectures}

After PhD dissertation defense in 1961 - Fr. Stanislaw started work as a lecturer in the Archdiocesan Higher Seminary in Bialystok. His didactic work fell on a period between 1961-2001. It involved lectures concerning dogmatic theology as well as scientific tutoring. As a professor, Stanislaw Piotrowski called himself a 'seeker theologian's'. He referred to two main forms of teaching during his lectures: pre-conciliciar and post-conciliar as well. He remembered that period of time as follows: 'I encountered with 'two theologies' over the 30 years, and when I took up a dogmatics department, I found the official theology - that is pre-conciliar'. ${ }^{6}$ Priest Piotrowski called this sort of theology an 'iron - having been practisioning for hundreds of years - based on the scholastical method'? Being a young lecturer, he always tried to make given knowledge current through numerous digressions which were devoted to numerous issues.

What is more, a wide variety of theological textbooks allowed Fr. Piotrowski to greater of lesser modifications during his lectures for seminarians. Every year, after having taken charge of dogmatics department, he introduced more and more comprehensive digressions on new contents which appeared among dogmatic people, especially those from West. There were inspirations of the Second Vatican Council along with its constitutions, documents and postulates that became a very unique period of his professor's. It was a time of substantive corrections. The lecturer was characterized by passionate devotion to the Church as well as intently listening to its voice. Following magisterium of the Church along with its documents and instructions were aimed at giving students a vivid faith of the Church. Furthermore, it is important to note that his lectures' language was not strictly academic. As he wrote in one article: 'I began my lectures by macaronisms - a couple

$4 \quad$ Ibidem, p. 85.

$5 \quad$ S. Piotrowski, Impresje na temat wykładów z teologii dogmatycznej w latach 1961-1991 wypowiedziane na sympozjum w dniu 16.11.1991 r. z okazji jubileuszu 30-lecia pracy profesorskiejw Wyższym Seminarium Duchownym w Biatymstoku, p. 100.

6 Ibidem.

$7 \quad$ Ibidem, p. 101. 
of Latin and Polish language" - stated Fr. Piotrowski. 'I started with ecclesiology - notes the author - perhaps because I liked that treaty most. I wrote my master's thesis about the Church and I obtained my doctoral degree just on this. I expressed my love towards the Church in written textbook entitled: One, Holy, Catholic, Apostolic. The Profile of Catholic Ecclesiology (For Students), Bialystok 1993'. ${ }^{9}$

\section{Ecclesiological books}

Professor Piotrowski's books about the Church are the fruit of long-standing didactic work. He wrote in his early note to textbook: Built on the Rock: 'I talk about my and your Church: the only, holy, catholic, apostolic to my theology adepts in the Theological Seminary in Bialystok since (FOR) 35 years. I try to learn their looking at the Church the way it is: crushed by sins and human weakness ${ }^{\prime 10}$. As being a professor of the Theological Seminary in Bialystok, Piotrowski realized that students needed both clear and brief guide to broad areas of teaching of the Church.

The priest noted in the introduction of the above-mentioned book entitled One, Holy, Catholic, Apostolic: 'My intention is to give a brief lecture about the Church to students of theological seminaries, being some kind of help while studying dogmatic theology. A textbook character defined the method, division and language as well. I would like to help with this publication to all these who 'give attention to' theology, seeking to both deepen their faith and knowledge about the Church $^{11}$. The priest-lecturer led his publications to a specific reader. He constantly listened very carefully to the needs of the Lord's house and sought new solutions as an experienced pedagogue.

After three years since having appeared the book: One, Holy, Catholic, Apostolic in print, he publishes the next one: Built on the Rock, addressed to an audience of secular students. The publication was supposed to revitalize the awareness of being a part of the Church among recipients. One can find a very valuable remark in the book Built on the Rock: 'I wish to show all secular people what the Church is, indicate that it is ours, that the house of worship is Jesus himself

$8 \quad$ Ibidem, p. 103.

$9 \quad$ S.Piotrowski,Jeden, święty, powszechny, apostolski.Zarys eklezjologiikatolickiej (dla studentów), Białystok 1993, p. 4.

10 Idem, Zbudowany na Skale, Białystok 1996, p. 10.

11 Idem, Jeden, święty, powszechny, apostolski. Zarys eklezjologii katolickiej (dla studentów), p. 7. 
Fundamental theology

connected to people, or people connected to Jesus, that we are all the Church and we are responsible for it (...) I had already seen lay people before the Council along with their role and tasks. Since that time, wherever I talk, I talk not only about responsibilities, but also about their rights. I say that they are not only in the God's house, but they constitute this as well. And I am writing this book in that light ${ }^{12}$. He started his theologian lecture with analysis of mystery of the Church. In the further part of the work one can find the study of the Holy Bible, especially images and Biblical names of the Church. Next, one can find an attempt to explain the origin of the house of Lord along with depicting its nature. The author accurately pointed to both visible and invisible structure of the house of prayer in order to give attention to its attributes. Under discussioned publication, Fr. Piotrowski also included eschatological character of pilgrimaging Church and its unity with this one in heaven. Additionally, he gave attention to issues concerning membership of the Church on the basis of its Council documents.

Apart from this, Fr. Piotrowski raised the issue of responsibility within the Church and for it as well as its assigned tasks in the modern world. These are annexes which deserve special attention because of their content: The First Vatican Council, encyclical Mystici Corposis, The Second Vatican Council - fundamental values of theology of the Council, its pastoral character and past-conciliar theology. It is also the bibliography which merits particular attention. A rich variety of documents of magisterium of the Church is supplemented with literature on the subject. Fr. Piotrowski most frequently referred to literary output by such theologians as: Urs von Balthasar, R. Bellarmine, L. Bouyer, Y. Congar, W. Granat, W. Kasper, H. de Lubac, S. Nagy, E. Ozorowski, K. Rahner, J. Ratzinger or H. Seweryniak.

The textbook Built on the Rock was published in 1996 in Bialystok, three years after the publication of One, Holy, Catholic, Apostolic. The author was urged to such a step because of the need to include topics which had not been undertaken or just done it insufficiently comprehensive. In the introduction, Ozorowski wrote as follows: 'The book Built on the Rock is not a repeat of One, Holy, Catholic, Apostolic. The content of both of them is the same, but a way of its message remains different. As far as the first was dedicated to theology adepts, the second one was addressed to all people, especially to secular believers. There is a lecture, apologia, explanation and encouragement in it. Fr. Piotrowski's writing and speaking is always hot, never tepid or cold. 
The same is with his book"13. As Ozorowski stressed, the content is 'similar', but not completely. There are differences which are noticeable. For instance, while analyzing the problem of mystery of the Church, in the textbook Built on the Rock the author asks a question concerning the source of difficulties in faith in the Church. Therewith, a reader receives a solid lecture about such issue. The consecutive difference is with Biblical names of the Lord's house. Apart from these abovementioned in the previous textbook, next ones add to it: 'New People of God', 'Community and Institution', 'Church as a Brotherly Community'. There were also some changes which occurred in showing images of the Church. For instance, 'The Bride of Christ' was added to those belonged to the canon. A novelty included in Piotrowski's teaching about the particular Church constitutes: pastoral parish councils, catholic movements as an activating factor of religious life in parishes, consecrated life as well as secular institutes. Particularly important is also directing reader's attention at the term of diocesan Synod and what are fields of activity for synodal groups. What separates listed textbooks is the fact that an area devoted to the Catholic Churches involves information concerning the Roman Catholic Church, the Eastern Catholic Churches along with the Orthodox Church. The most extensive note concerns post-protestant communities: the Evangelical Church of the Augsburg Confession, the Polish Reformed Church, the Anglican Church, the Methodist Church, the Baptist Church, the Adventist Church, the Quaker Church, The Old Catholic Church as well as the Pentecostal Church. A whole textbook is culminated with a chapter which analyzes a matter of ecumenism.

Fr. Piotrowski's books devoted to the Church met with approval of many theology students. There were many reasons for that. One of them is the fact that despite specialistic terminology, the form of conveying knowledge still remained accessible. Book publications by Piotrowski clearly correspond to a need of spiritual renewal of theology of the Catholic Church after the Second Vatican Council.

\section{Theological articles}

The author of articles on theological subject had been a professor and theology lecturer for many years. His knowledge and experience in working with students resulted in numerous publications. The articles on theological subject were published by him mainly in 'Ecclesiastical News of Bialystok Archdiocese' since 1992.

13

Ibidem, p. 8 . 
Fundamental theology

The first text was entitled 'Tasks of the Church in the Contemporary World'14 in which the author focused attention on the Church which comes to particular communities and people's aid. He stressed in his articles that the house of God has a task to meet people with its merciful work, accept good wherever it is, support it and cooperate with it as well.

According to Piotrowski, it is crucial to perceive the Church as a community of Christians promoting human activity. He underlined in many articles that lay people: 'acting in their areas are supposed to develop not only in their lines of action, but also teach other people to recognize that divine law is written into life of earthly state ${ }^{15}$. Father Piotrowski noted in a text: Problematic aspects of Vocation and Mission of Secular Catholics in the Church and in the World that council fathers did not give a comprehensive definition of secular people. The Second Vatican Council only pointed that one should understand something called 'secular' as a baptized man, a member of God's nation participating in a priestly, prophet and majestic office of Christ. They are these who belong to neither to the priesthood nor the monkhood.

As a theologian and priest as well, the author wrote: 'One cannot trade secular people against priests, unduly stressing existing differences and distinctive features between them as well as efface these differences. Eliciting distinctiveness (in the way of life, spirituality, mission) enables to perceive how to express proper responsibility in the Church and in the world. He also asked a question: What can the house of Lord offer to human family? His answer went as follows: 'participation in divine life and additionally faith cure that was hurt by original sin of human nature and depicting people's dignity. In this way, the Church contributes in order to both individual and all humanity become more human'16.

Articles written by Piotrowski touch upon and explain relations between the Church and the world. According to the author, it is not only the Church that has an impact on the world, but also our world enriches it. Scientific development, technological progress, cultural achievements - all these are beneficial to ecclesial community. Fr. Piotrowski notices that the Church itself enriches thanks to progress

14 S.Piotrowski,Zadania Kościoławświecie wspótczesnym, „Wiadomości Kościelne Archidiecezji Białostockiej” 18(1992) no. 1, p. 78-80.

15 Idem, Problematyka powołania i postannictwa katolików świeckich $w$ Kościele i świecie, „Wiadomości Kościelne Archidiecezji Białostockiej” 29(2003) no. 1, p. 138.

16 Ibidem, p. 140. 
of social life. 'This is not because the Church lacks something, but because it is easier to adapt to contemporary times thanks to world achievements' ${ }^{17}$.

As a lecturer of the Theological Seminary, he was always true to the teaching of our Lord. He wrote in one of his publications containing reflections on lectures: 'I declare that I diligently retain teaching of magisterium of the Church. However, I wish and do this - to go ahead, not ignoring questions and new solutions as time carries' ${ }^{18}$.

\section{Concluding remarks}

The aim of this article was to show path to love for the Church by Fr. Stanislaw Piotrowski as well as to provide answers to a question: What is value of its teaching? Furthermore, what is its subject and sources of it? Performed research of his theological output on four points demand undertaking of assessment everything what the author wrote. By making such an attempt, it was necessary to remind crucial facts of scholar's life. There were family house, vocation to priestly service and undertaken academic work which turned out to be essential in understanding his thoughts and attitude to life.

Examining literature led for the formulation of the following conclusions: Stanislaw Piotrowski's teaching complies with tradition of the Church, follows from conciliar teaching and has got deep roots in the Bible. Admittedly, the priest faithfully conveys teaching of the Church and does not insert any novelty to its content, but he undoubtedly does it in an unconventional way, in the benefit of reaching a wider audience.

\section{KOŚCIÓt W ŻYCIU I NAUCZANIU KS. STANIS ŁAWA PIOTROWSKIEGO}

Przedmiotem zainteresowania niniejszego artykułu jest ukazanie ks. Stanisława Piotrowskiego jako teologa, który umiłował nauczanie o Kościele. Jego praca naukowa znajdowała odzwierciedlenie w życiu tegoż kapłana, a także historii Wspólnoty lokalnej. Przy czym na uwagę zasługuje fakt, iż profesor AWSD w Białymstoku nie zasłynął z ilości zredagowanych tekstów naukowych,

17 S.Piotrowski, Katechizm wżyciu Kościoła, „Wiadomości Kościelne Archidiecezji Białostockiej” 19(1993) no. 2, p. 98.

18 Idem, Impresje na temat wykładów z teologii dogmatycznej w latach 1961-1991 wypowiedziane na sympozjum $w$ dniu 16.11.1991 $r$. z okazji jubileuszu 30-lecia pracy profesorskiej w Wyższym Seminarium Duchownym w Biatymstoku, p. 106. 
Fundamental theology

lecz niezwykłej zdolności odkrywania Boga oraz mocnego trwania w wierze, mimo przeciwności losu. Celem życia "teologa poszukującego" było zaszczepianie w sercach i umysłach studentów wierności Magisterium ecclesiae oraz umiłowanie Kościoła. Pokłosiem wieloletniej analizy dokumentów i instrukcji oraz pracy dydaktycznej stały się zredagowane przez niego książki o Kościele: Zbudowany na Skale oraz Jeden, święty, powszechny, apostolski. Celem artykułu było również udzielenie odpowiedzi na pytanie o źródła eklezjologii w ujęciu ks. Piotrowskiego. Przeprowadzone w czterech punktach badania dorobku eklezjologicznego domagają się podjęcia krótkiej oceny tego, co ów kapłan napisał. Podejmując tę próbę oceny należało przypomnieć najistotniejsze fakty z biografii badacza - czas spędzony w domu rodzinnym, powołanie do służby kapłańskiej oraz podjętą pracę naukową. Badania literatury eklezjologicznej doprowadziły do sformułowania następujących wniosków: teologia ks. Stanisława Piotrowskiego jest zgodna z Tradycją Kościoła. Wszystkie wykładane traktaty wypływają z nauczania Soborowego i posiadają głębokie korzenie w Biblii. Wprawdzie ks. Stanisław Piotrowski, przekazując wiernie naukę Kościoła, nie wprowadza do treści żadnych nowości, ale niewątpliwie czyni to w nieszablonowy sposób, z myślą o jak najlepszym dotarciu do słuchacza i czytelnika.

Słowa kluczowe: Kościół, miłość do Kościoła, Zbudowany na skale, wspólnota, Stanisław Piotrowski, katecheza, nauczanie teologiczne.

\section{Bibliography:}

1. Kułakowski K., Profesorowie i wyktadowcy, [in:] Archidiecezjalne Wyższe Seminarium Duchowne w Białymstoku 1945-1995, S. Hołodok ed., Białystok 1995.

2. Piotrowski S., Impresje na temat wyktadów z teologii dogmatycznej $w$ latach 1961-1991 wypowiedziane na sympozjum w dniu 16.11.1991r. z okazji jubileuszu 30-lecia pracy profesorskiej w Wyższym Seminarium Duchownym w Białymstoku, „Wiadomości Kościelne Archidiecezji Białostockiej” 17(1991) no. 4.

3. Piotrowski S., Jeden, święty, powszechny, apostolski. Zarys eklezjologii katolickiej (dla studentów), Białystok 1993.

4. Piotrowski S., Katechizm w życiu Kościoła, „Wiadomości Kościelne Archidiecezji Białostockiej" 19(1993) no. 2.

5. Piotrowski S., Problematyka powotania i postannictwa katolików świeckich $w$ Kościele i świecie, „Wiadomości Kościelne Archidiecezji Białostockiej” 29(2003) no. 1.

6. Piotrowski S., Zadania Kościoła w świecie wspótczesnym, „Wiadomości Kościelne Archidiecezji Białostockiej” 18(1992) no. 1.

7. Piotrowski S., Zbudowany na Skale, Białystok 1996. 